\title{
Expression of a Rice Chlorophyll a/b Binding Protein Promoter in Sweetpotato
}

\author{
Guo-qing Song ${ }^{1}$, Hideo Honda, and Ken-ichi Yamaguchi ${ }^{2,3}$ \\ Functional Chemicals Laboratory, Mitsui Chemicals, Inc. 1144, Togo, Mobara-shi, Chiba, 297-0017, \\ Japan
}

\begin{abstract}
AdDitional IndeX words. CAB, GUS, Ipomoea batatas, tissue-specific promoter, transgenes, transgenic plant
Abstract. Leaves are usually the target tissue for expressing transgenes conferring resistances to herbicides, pests, and diseases. To achieve leaf-specific expression, a light-harvest chlorophyll $\mathbf{a} / \mathrm{b}$ binding protein $(C A B)$ of photosystem-II (CAB2) promoter (CAB2-p) from rice (Oryza sativa L.) and the cauliflower mosaic virus 35S promoter were fused to the $\beta$-glucuronidase (GUS) reporter and subsequently evaluated in transgenic sweetpotato [Ipomoea batatas L. (Lam.)]. The 35S promoter-directed GUS activities varied from 46.0 to $61.2 \mathrm{nmol} 4$-methyl-umbelliferyl- $\beta$ D-glucuronide (4-MU) per minute per milligram of protein in leaf, stem, primary, and storage roots. In contrast, the $C A B 2$-p directed an uneven distribution of GUS activities (4-MU at 1.1 to $12.6 \mathrm{nmol} \cdot \mathrm{min}^{-1} \cdot \mathrm{mg}^{-1}$ protein); GUS activity in mature leaves was $\approx 12$-fold as high as that in storage roots. In addition, GUS assay in leaf tissues revealed that $C A B 2$-p enabled a developmentally controlled and light-regulated GUS expression. These results indicate that the rice $C A B 2$-p could be used to drive leaf-specific expression of linked genes in sweetpotato.
\end{abstract}

Sweetpotato is one of the most important food crops in many developing countries as a result of its nutritional value, ease of cultivation, and high productivity of storage roots. It is also an important industrial material for producing starch, sugar, and alcohol (Otani and Shimada, 2002). Transformation provides a powerful tool for genetic manipulation of sweetpotato by efficiently introducing genes of interest for either improvement of crop traits or obtaining novel materials for industry (Otani and Shimada, 2002; Otani et al., 2003; Wakita et al., 2001). To obtain sufficient expression levels of transgenes in target tissues of genetically engineered sweetpotato plants, the selection of promoters is crucial. To date, few tissue-specific promoters have been evaluated in sweetpotato as well as constitutive promoters (Gama et al., 1996; Kimura et al., 2001; Morán et al., 1998; Newell et al., 1995; Song et al., 2004; Wakita et al., 2001). Leaf-specific promoters are preferable to constitutive promoters when transgenes, including most of those conferring resistances to herbicides, insects, and diseases, are targeted principally in green tissues of sweetpotato. This is because leafspecific instead of constitutive expression of target genes can help to minimize the public concerns about the impact of transgene expression on food safety in nontargeted storage roots.

Light-harvesting chlorophyll $\mathrm{a} / \mathrm{b}$ binding protein promoters are an important source for leaf-specific promoters (Churin et al., 2003; Lamppa et al., 1985; Luan and Bogorad, 1992; Nagy et al., 1986; Piechulla et al., 1991; Simpson et al., 1986; Sugiyama et al., 2001). Fourteen genes encoding members of the tomato (Solanum lycopersicum L.) chlorophyll a/b binding protein family were found to be expressed in leaf tissue (Piechulla et al., 1991). Rice phytochrome was found biolog-

Received for publication 19 July 2006. Accepted for publication 13 Mar. 2007. This research was supported by the New Energy and Industrial Technology Development Organization (NEDO), Japan.

${ }^{1}$ Current address: Plant Transformation Center, Department of Horticulture, Michigan State University, East Lansing, MI 48824.

${ }^{2}$ Current address: Lab for Sustainable Horticulture, Minami Kyushu University,

Hibarigaoka, Takanabe-cho, Miyazaki 884-0003, Japan.

${ }^{3}$ Corresponding author. E-mail: keny@nankyudai.ac.jp. ically active in transgenic tobacco (Nicotiana tabacum L.) (Kay et al., 1989). The chlorophyll a/b binding protein of photosystemII promoter (CAB2-p) isolated from photosystem-II of rice displayed high activity in green tissues of transgenic rice (Tada et al., 1991; Tsuchida et al., 2001) and was also found active in tobacco (Sakamoto et al., 1991). Therefore, rice CAB2-p is likely an effective promoter for directing efficient expression of linked genes in green tissues of sweetpotato.

The aim of this study was to evaluate the rice $C A B 2-\mathrm{p}$ for directing leaf-specific expression of model transgenes in hexaploid sweetpotato plants.

\section{Materials and Methods}

Vector and Agrobacterium strain. The rice CAB2-p (XbaI-BamHI fragment), 848 base pairs (Sakamoto et al., 1991), was fused with $\beta$-glucuronidase (GUS) in the binary vector backbone of pBI-H1 whose T-DNA region contains a hygromycin phosphotransferase gene (hpt) and a neomycin phosphotransferase gene (nptII), to give pBIH1CG containing CAB2-p-GUS (Fig. 1). Agrobacterium tumefaciens (Smith and Towns) Conn. strain EHA105:pBIH1CG was used for transformation. The binary vector $\mathrm{pIG} 121 \mathrm{Hm}$ containing a GUS expression cassette under the $35 \mathrm{~S}$ promoter (35S-GUS) was previously introduced into sweetpotato plants (Song et al., 2004).

Transformation. Transformation using EHA105: pBIH1CG was performed according to Song et al. (2004). In vitro cultures of sweetpotato 'Beniazuma' were maintained in Magenta GA7 (Magenta Corp., Chicago) boxes each containing $50 \mathrm{~mL}$ of medium SGM [Linsmaier and Skoog (1965) medium (LS) $+2.85 \mu \mathrm{M}$ indole-3-acetic acid] $\}$. Unless otherwise mentioned, all media contained $0.32 \%$ gellan gum and all in vitro cultures were maintained at $26{ }^{\circ} \mathrm{C}$ under a $16-\mathrm{h}$ photoperiod of $30 \mu \mathrm{mol} \cdot \mathrm{m}^{-2} \cdot \mathrm{s}^{-1}$ using cool white fluorescent tubes. Stems, from 6-week-old stock cultures, and all leaves removed, were cut transversely into explants 6 to $10 \mathrm{~mm}$ in length and sliced in half along the axis were the explants. EHA105:pBIH1CG was suspended in liquid embryogenic 


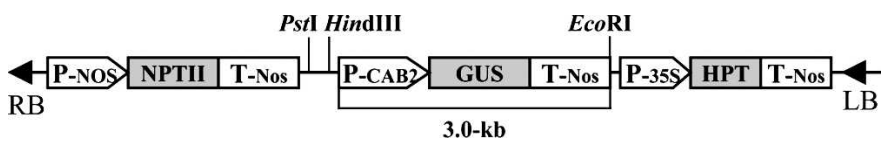

Fig. 1. Schematic representation of the T-DNA region of the binary vector pBIH1CG. P-nos = nopaline synthase $($ nos) promoter; NPTII = neomycin phosphotransferase coding region (kanaycin resistance); $\mathrm{T}$-nos $=$ nos gene terminator; $\mathrm{P}$-cab2 = rice $C A B 2$ promoter; $\mathrm{GUS}=\beta$-glucuronidase coding region; $\mathrm{P}-35 \mathrm{~S}=\mathrm{CaMV} 35 \mathrm{~S}$ promoter; $\mathrm{HPT}=$ hygromycin phosphotransferase coding region (hygromycin resistance); $\mathrm{RB}=$ right $\mathrm{T}$-DNA border; $\mathrm{LB}=$ left T-DNA border; PstI, EcoRI, and HindIII = unique restriction endonucleases at T-DNA region; $\mathrm{CAB} 2=$ chlorophyll $\mathrm{a} / \mathrm{b}$ binding protein of photosystem-II; GUS $=\beta$-glucuronidase.

callus induction medium [ECIM (LS + $6.49 \mathrm{~mm}$ 4-fluorophenoxyacetic acid)] containing $100 \mu \mathrm{M}$ acetosyringone (AS) (Song et al., 2004). Explants were incubated with suspension cells $\left(\mathrm{OD}_{600}=0.8\right)$ for $20 \mathrm{~min}$ at $30{ }^{\circ} \mathrm{C}$. Cocultivation was carried out on ECIM $+100 \mu \mathrm{M}$ AS in $100 \times 20$-mm petri dishes for $3 \mathrm{~d}$ in the dark. Selection of transformed embryogenic calluses first began with culture on ECIM $+50 \mathrm{mg} \cdot \mathrm{L}^{-1}$ kanamycin $(\mathrm{Km})+250 \mathrm{mg} \cdot \mathrm{L}^{-1}$ cefotaxime for 6 weeks and then transfer to ECIM $+30 \mathrm{mg} \cdot \mathrm{L}^{-1}$ hygromycin $+250 \mathrm{mg} \cdot \mathrm{L}^{-1}$ cefotaxime for 9 weeks both in the dark. Regeneration of transgenic plants from selected friable calluses was performed on regeneration medium (LS $+15.13 \mu \mathrm{M}$ abscisic acid +2.89 $\mu \mathrm{M}$ gibberellic acid) for 4 weeks under a 16 -h photoperiod of $30 \mu \mathrm{mol} \cdot \mathrm{m}^{-2} \cdot \mathrm{s}^{-1}$. Selected transgenic plants each with six to 10 leaves were planted in $20 \times 30-\mathrm{cm}$ (diameter $\times$ height) plastic pots using planting medium and placed in a growth chamber at $26{ }^{\circ} \mathrm{C}$ under a $16-\mathrm{h}$ photoperiod at a light intensity of 50 $\mu \mathrm{mol} \cdot \mathrm{m}^{-2} \cdot \mathrm{s}^{-1}$ and $50 \%$ relative humidity.

Transgenic plants each with a single copy of 35S-GUS (Song et al., 2004) as well as nontransgenic plants were used as controls. They were all maintained under the same environmental conditions as those of the transgenic plants with $C A B 2$ p-GUS.

Southern BLOT ANALYSIS. DNA samples were isolated from leaves of in vitro cultured plants according to the method described by Rogers and Bendich (1985). Twenty micrograms of DNA was digested with HindIII or PstI + EcoRI, electrophoresed in $0.8 \%$ agarose gel, and then blotted onto a Hybond $\mathrm{N}^{+}$-nylon membrane (Amersham Biosciences, Piscataway, NJ). A 1.9-kb SmaI-SacI fragment containing the GUS coding region was used as a probe. Labeling, hybridization, and detection were performed using the Alkphos Direct Kit (Amersham Biosciences) following the manufacturer's instructions.

$\beta$-GLuCURONIDASE assays. Location of GUS activity in plant tissues was determined histochemically according to the procedure of Jefferson et al. (1987). All tissues for GUS staining were vacuum-infiltrated for $20 \mathrm{~s}$, fixed for $30 \mathrm{~min}$ in $4 \%$ formaldehyde solution at room temperature, and incubated for $12 \mathrm{~h}$ at $37^{\circ} \mathrm{C}$ in assay buffer containing $1 \mu \mathrm{M} \mathrm{X}$ Gluc. The whole procedure was carried out in the dark. Chlorophyll was removed from the tissues using $70 \%$ ethanol rinses. Quantitative measurement of GUS activity was performed as described by Stomp (1992) with protein concentration measured according to Bradford (1976). GUS activities in different tissues were analyzed for significance by analysis of variance (ANOVA) with mean separation by standard deviation; PROCGENMOD (version 8.2; SAS Institute, Cary, NC) was used.

For in vitro plant tissues, GUS expression was assayed in the whole plantlet (4-week-old) and leaves excised from 8-weekold plantlets. To investigate the light response of $C A B 2$-p-GUS expression, in vitro shoot tips or internode sections, 1 to $2 \mathrm{~cm}$ in length, were cultured in Magenta GA7 boxes containing each $50 \mathrm{~mL} \mathrm{GM}+30 \mathrm{mg} \cdot \mathrm{L}^{-1}$ hygromycin for $7 \mathrm{~d}$ in darkness. Half of the obtained materials were submitted for GUS assays immediately and the remainder cultured for $2 \mathrm{~d}$ or more under a $16-\mathrm{h}$ photoperiod at $30 \mu \mathrm{mol} \cdot \mathrm{m}^{-2} \cdot \mathrm{s}^{-1}$ before GUS staining. GUS expression of potted plants was assayed using leaves, stems, storage, and primary roots. To enable more staining solution to enter the cells, the surface of the mature leaves was gently scored perpendicular to the midrib with a surgical blade, stem sections, 2 to $3 \mathrm{~cm}$ in length, were cut in half along the axis, and storage roots were either scored along the axis or sliced into disks perpendicular to the axis.

\section{Results}

Selection, Regeneration, AND MOLECULAR aNALysis OF TRANSGENIC PLANTS. Most inoculated stem explants, 56 of 90 , produced $\mathrm{Km}$-resistant calluses from the wounded edges in $\approx 6$ weeks. After selection with $30 \mathrm{mg} \cdot \mathrm{L}^{-1}$ hygromycin, 22 of 56 explants had bright yellow and friable callus clusters from which numerous regenerants formed through somatic embryogenesis. The 22 explants gave rise to 110 morphologically normal plants obtained after 20 weeks also had GUS-positive leaves, indicating that the two-step kanamycin-hygromycin selection method enables efficient production of transgenic sweetpotato plants (Song et al., 2004).

Southern hybridization showed that the expected $3.0-\mathrm{kb}$ EcoRI-PstI fragment was detected in each of the eight randomly selected transgenic lines and was absent in the nontransformed control (Fig. 2A). When HindIII-digested DNA samples were hybridized to the $1.9-\mathrm{kb}$ probe, the expected fragments were observed in all eight transgenic lines; six had a single band and two had two discrete bands; there was no signal in nontransformed plants (Fig. 2B). HindIII cuts outside of the
A

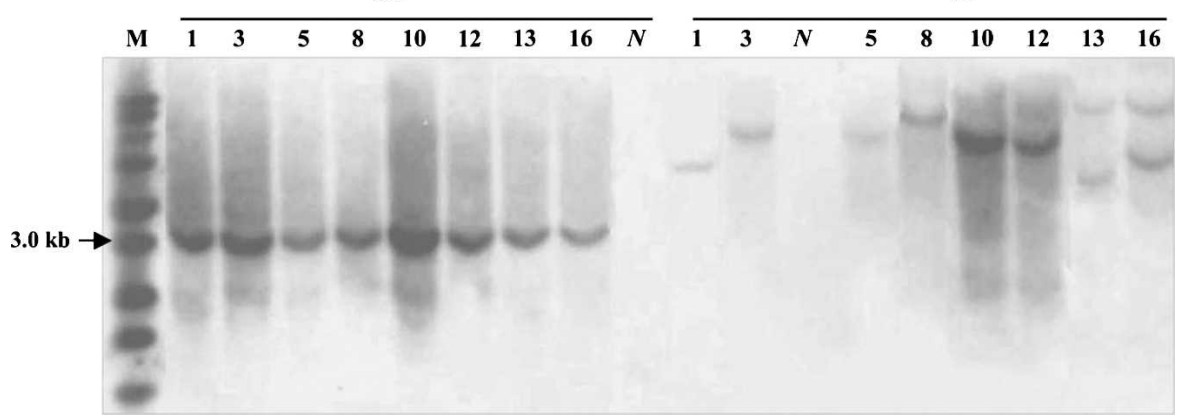

Fig. 2. Southern hybridization analysis of the GUS reporter gene in sweetpotato. DNA samples were digested by Pst and EcoRI (A) and HindIII (B) and hybridized with a 1.9-kb probe containing the GUS coding region. Lanes 1, 3, 5, 8, 10, 12, 13, and 16, and transgenic lines CG1, CG3, CG5, CG8, CG10, CG12, CG13, and CG16; lane N, nontransformed wild type $(N)$; lane $\mathrm{M}, \lambda$ DNA 1-kb marker. GUS $=\beta$-glucuronidase. 
GUS gene and an uncertain site in the genomic DNA. Therefore, the differences in the patterns of the hybridization bands most likely represent the copy numbers as well as random integration of the GUS gene. These results confirmed stable integration of CAB2-p-GUS. The six transgenic lines each with a single T-DNA insert were subsequently used for GUS assay.

LEAF SPECIFICITY OF CHLOROPHYLL A/B BINDING PROTEIN OF PHOTOS Y S T E M - I I P R O MO TER$\beta$-gLUCURONIDASE EXPRESSION. A typical pattern of $C A B 2-p-G U S$ expression was present in all six transgenic lines. In 4-week-old plantlets grown in vitro under $16 \mathrm{~h}$ of $30 \mu \mathrm{mol} \cdot \mathrm{m}^{-2} \cdot \mathrm{s}^{-1}$ light, blue staining indicating that the $C A B 2-\mathrm{p}-\mathrm{GUS}$ activity was detected and varied not only in green tissues (leaves, petioles, and stems), but also in roots containing no visible chlorenchyma (Fig. 3A). Similarly, blue staining in soil-grown plants, 16-h photoperiod, $50 \mu \mathrm{mol} \cdot \mathrm{m}^{-2} \cdot \mathrm{s}^{-1}$ light, was stronger and not limited to the green tissues as leaves, petioles, and stems (Fig. $3 \mathrm{~B}, \mathrm{C})$. Faint blue staining, indicating weak expression of CAB2-pGUS, was also observed in primary and storage roots (Fig. 3D, E). In addition, intense blue staining indicated more activity of $C A B 2-p-G U S$ in mesophyll, stem vascular, and the cortex and vascular cylinder of the developing storage root. Unlike the expression of $C A B 2-p-G U S$, the $35 \mathrm{~S}$ directed a constitutive expression of GUS in all six transgenic lines each containing a single copy of the 35S-GUS. In vitro plants displayed high GUS activity (dark blue staining) in the whole plant (Fig. 3F). Similarly, a high level of expression of the 35S-GUS (intense blue staining) was present in leaves, stems, and primary and storage roots from potted plants (Fig. 3G-J). No blue staining was observed in nontransformed plant tissues.

GUS activities directed by the $C A B 2$-p were consistent with histochemical GUS staining and showed variability for different plant organs. The highest GUS activity, $4 \mathrm{MU}$ at 12.6 $\mathrm{nmol} \cdot \mathrm{min}^{-1} \cdot \mathrm{mg}^{-1}$ protein, was observed in the mature leaves. This contrasts with an 11-fold decrease in GUS activity in developing storage roots (Table 1). In comparison, GUS activity directed by the $35 \mathrm{~S}$ promoter was similar in leaves, stems, and roots (Table 1). These results showed that use of the rice $C A B 2-\mathrm{p}$ enabled a leaf-specific directed expression of linked genes in the green tissues of sweetpotato.

DeVelopmental REgUlation OF CHLOROPHYLL A/B BINDING PROTEIN OF PHOTOSYSTEM-II PROMOTER- $\beta$-GLUCURONIDASE EXPRESSION. Variation in CAB2-p-GUS expression was observed in stained in vitro leaves. Leaves at the apex stained II promoter- $\beta$-glucuronidase.
Organs from soil-grown plants

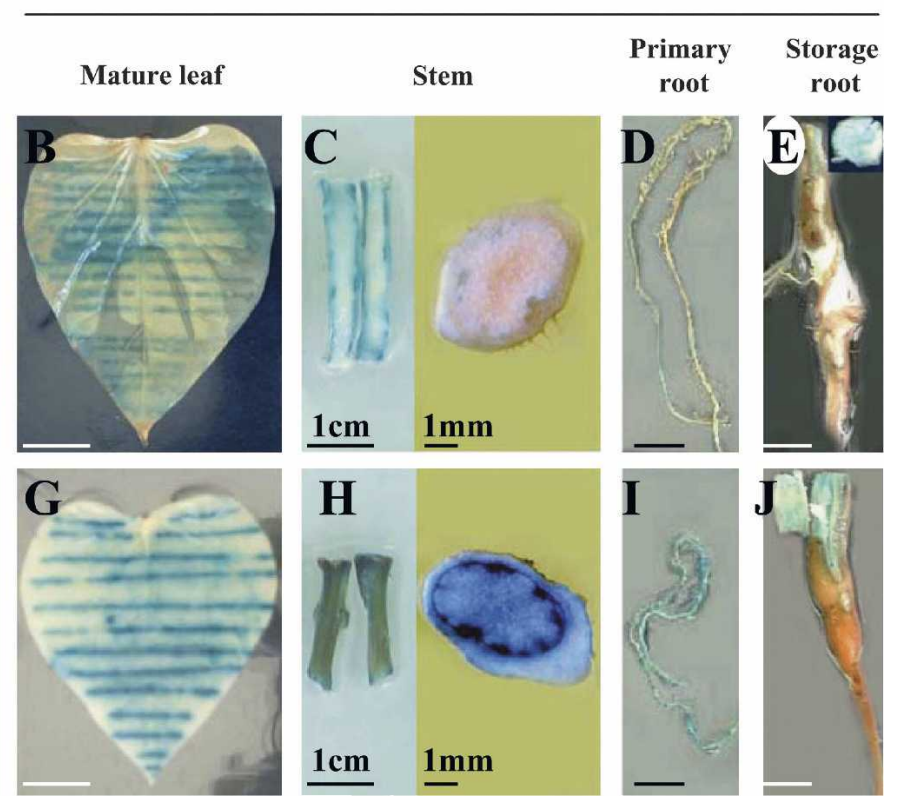

Fig. 3. Expression of CAB2-p-GUS and 35S-GUS in transgenic sweetpotato CG10 (A-E) and S8 (F-J), respectively. All tissues were stained at $37^{\circ} \mathrm{C}$ for $12 \mathrm{~h}$ in the dark. The circle in the upper corner of $3 \mathrm{E}$ is a stained root section. Bars $=1 \mathrm{~cm}$, except in $(\mathbf{C})$ and $(\mathbf{H}) . C A B 2-\mathrm{p}-\mathrm{GUS}=$ chlorophyll $\mathrm{a} / \mathrm{b}$ binding protein of photosystem-

Table 1. Expression of $C A B 2-\mathrm{p}-\mathrm{GUS}$ in different tissues of transgenic sweetpotato plants.

\begin{tabular}{|c|c|c|c|}
\hline \multirow[b]{2}{*}{ Plant tissue } & \multicolumn{3}{|c|}{ 4-methyl-umbelliferyl- $\beta$-D-glucuronide $\left[\right.$ mean $\pm \mathrm{sD}\left(\mathrm{nmol} \cdot \mathrm{min}^{-1} \cdot \mathrm{mg}^{-1}\right.$ protein $\left.)\right]$} \\
\hline & Nontransformed control $^{z}$ & $C A B 2-\mathrm{p}-\mathrm{GUS}^{\mathrm{y}}$ & $35 \mathrm{~S}-\mathrm{GUS}^{\mathrm{x}}$ \\
\hline Leaf & $0.3 \pm 0.1$ & $12.6 \pm 1.8$ & $61.2 \pm 15.5$ \\
\hline Stem & $0.3 \pm 0.1$ & $9.2 \pm 0.4$ & $54.6 \pm 11.5$ \\
\hline Primary root & $0.3 \pm 0.1$ & $4.3 \pm 1.4$ & $57.3 \pm 15.4$ \\
\hline Storage root & $0.2 \pm 0.1$ & $1.1 \pm 0.2$ & $46.0 \pm 7.8$ \\
\hline
\end{tabular}

${ }^{\mathrm{z}}$ Mean value of six nontransgenic plants.

${ }^{y}$ Mean value of six independent transgenic events each containing a single copy of CAB2-p-GUS.

${ }^{\mathrm{x}}$ Mean value of six independent transgenic events each containing a single copy of 35S-GUS.

$C A B 2-\mathrm{p}-\mathrm{GUS}=$ chlorophyll $\mathrm{a} / \mathrm{b}$ binding protein of photosystem-II promoter- $\beta$-glucuronidase.

less intensively in comparison with older leaves from the apical meristem as depicted in Figure 3A; however, staining diminished in old and yellow leaves. Similarly, expression of $C A B 2-$ p-GUS resulted in intensive blue staining in mature leaves and less in old leaves of the potted plants. In contrast to CAB2-pGUS, expression of the 35S-GUS yielded intense blue staining in all leaves from both the in vitro-cultured plants (Fig. 3F) and the potted plants (data not shown).

Developmental regulation of CAB2-p was assessed by assaying GUS activity in four leaf samples from the apical meristem for each of the six independent transgenic lines from in vitro-grown plants (Fig. 4A). CAB2-p-GUS activity was $\approx 5$ to 6 -fold higher in leaves 5 and 6 in comparison with leaves 9 and 10 (Fig. 4B). In contrast, the activity of the $35 \mathrm{~S}$ promoter did not vary significantly among leaves (Fig. 4B).

LIGHT-REGULATED EXPRESSION OF CHLOROPHYLL A/B BINDING PROTEIN OF PHOTOSYSTEM-II PROMOTER- $\beta$-GLUCURONIDASE. Activity of the CAB2-p-GUS was also evaluated on etiolated in vitro tissue. Plant tissue forming in the absence of light was free of visible blue pigmentation (Fig. 5). However, after a 2-d exposure of the etiolated shoots to light conditions (16-h 
A

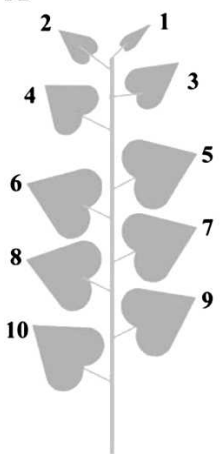

B

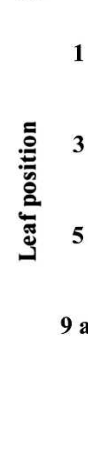

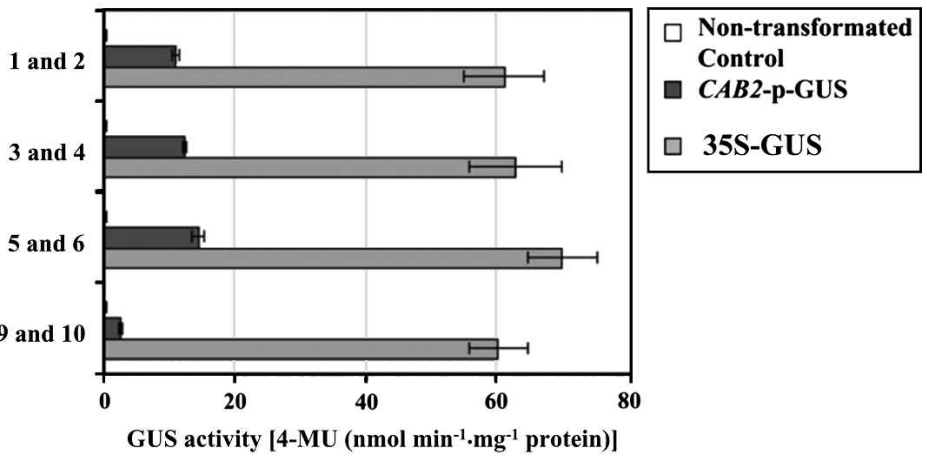

Fig. 4. Effect of leaf age on GUS expression in sweetpotato plants. (A) Leaf positions (the fifth or sixth leaf is usually the first fully expended leaf cultured in vitro; the ninth and 10th leaves are senescing). (B) Expression of CAB2-p-GUS (single copy lines: CG1, CG3, CG5, CG8, CG10, and CG12) and 35S-GUS (single copy lines: S1, $\mathrm{S} 2, \mathrm{~S} 3, \mathrm{~S} 6, \mathrm{~S} 7$, and S8) in sweetpotato leaves from different positions. 4-MU = 4-methyl-umbelliferyl- $\beta$-Dglucuronide. Vertical bars indicate the sDS. CAB2-p-GUS = chlorophyll a/b binding protein of photosystem-II promoter- $\beta$-glucuronidase.

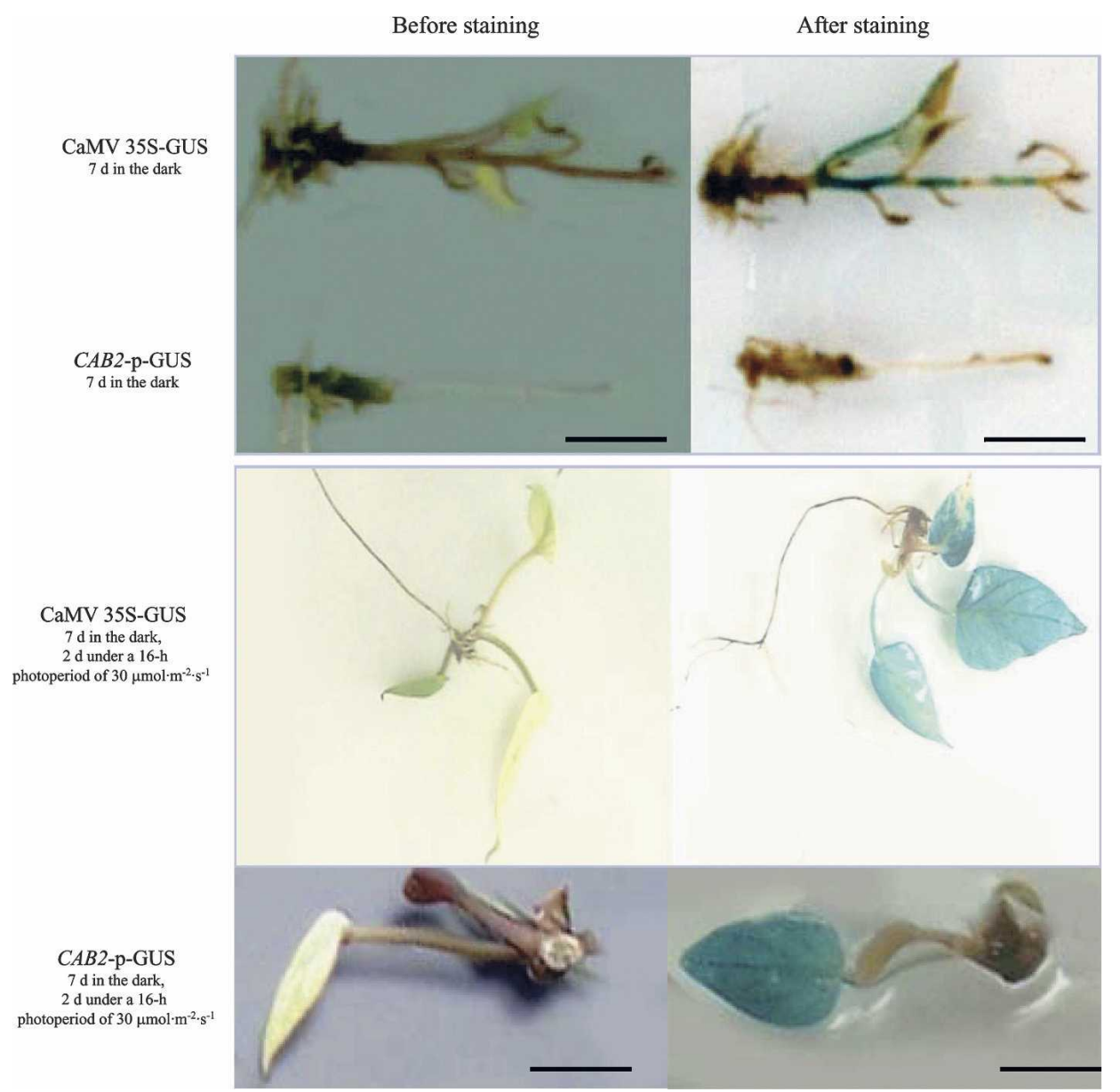

Fig. 5. Expression of CAB2-p-GUS (line CG10) and 35S-GUS (line S8) in sweetpotato tissues cultured under different light conditions. In vitro shoot tips or internode sections were cultured $7 \mathrm{~d}$ in darkness and subsequently submitted for GUS assays either immediately or after a 2-d culture under a 16 -h photoperiod at $30 \mu \mathrm{mol} \cdot \mathrm{m}^{-2} \cdot \mathrm{s}^{-1}$ staining. Bars $=1 \mathrm{~cm}$. CAB2-p-GUS $=$ chlorophyll $\mathrm{a} / \mathrm{b}$ binding protein of photosystem-II promoter- $\beta$ glucuronidase.

photoperiod, $30 \mu \mathrm{mol} \cdot \mathrm{m}^{-2} \cdot \mathrm{s}^{-1}$ ), faint blue staining was detected (Fig. 5). In etiolated shoots with the 35S-GUS, intense blue staining was not obviously influenced by light conditions (Fig. 5).

\section{Discussion}

LEAF-SPECIFIC RESPONSES FOR THE RICE CHLOROPHYLL A/B BINDING PROTEIN OF PHOTOSYSTEM-II PROMOTER. Expression patterns of the rice $C A B 2$-p had been previously investigated in transgenic tobacco (Sakamoto et al., 1991) and rice (Tada et al., 1991), respectively. In tobacco, the rice $C A B 2-p$ was expected to be active only in chlorenchyma cells. However, the GUS activity directed by the $C A B 2-\mathrm{p}$ was not completely restricted to chlorenchyma tissues, and the activity in leaves was $\approx 2$-fold higher than that in roots (Sakamoto et al., 1991). The imperfect recognition of a monocot gene promoter in dicot systems was postulated to be responsible for the limited expression of the rice $C A B 2$ $\mathrm{p}$ in nonchlorenchyma cells of tobacco. In rice, expression of the rice $C A B 2$-p was tissue-specific, although the $C A B 2$-p-GUS activity was also observed in nongreen organs such as anther, pollen, stigma, and roots of transgenic rice. The rice $C A B 2$-p-GUS activity in leaves was $\approx 120$-fold higher than that in roots (Tada et al., 1991). In sweetpotato, we found that the rice $C A B 2$-p-GUS activity was significantly greater in leaves in comparison with primary roots $(\approx 2$-fold $)$ (Table 1). Our results are consistent with previous research on tobacco (Sakamoto et al., 1991).

The detectable expression of rice $C A B 2$-p in nonchlorenchyma cells of tobacco, rice, and sweetpotato plants reflects the leaf-specific characteristic of the rice $C A B 2-\mathrm{p}$. In higher plants $C A B$ products, which bind chlorophyll $\mathrm{a} / \mathrm{b}$ and assembles it into the light-harvest complex, it is controlled by a complex of regulatory networks related to phytochrome (Bischoff et al., 1997; Karlin-Neumann et al., 1988; Piechulla et al., 1991; Thompson and White, 1991), development (Brusslan and Tobin, 1992; Chang and Walling, 1992; Kretsch et al., 1995), and circadian rhythms (Kaldis et al., 2003; Millar and Kay, 1991; Sugiyama et al., 2001). Native $C A B$ expression in dark-grown seedlings has also been reported in Arabidopsis thaliana (L.) Heynh. (Brusslan and Tobin, 1992) and soybeans [Glycine $\max (\mathrm{L}$.$) Merr.] (Chang and Walling,$ 1992). Our results are consistent with theoretical expectations 
of previous research, which suggest the $C A B$ promoter is only active in tissues containing chloroplasts.

Storage root is usually the harvest target for most sweetpotato cultivars. Our results showed that the CAB2-p-GUS in leaves was greater than activity in roots by a factor of 12 , thereby indicating the potential use of the rice $C A B 2-\mathrm{p}$ for devising leaf-specific gene expression in sweetpotato.

STRENGTH OF THE RICE CHLOROPHYLL A/B BINDING PROTEIN OF PHOTOSYSTEM-II PROMOTER. Expression levels of linked genes are generally related to promoters as well as plant species (Ni et al., 1995; Wilmink et al., 1995). GUS activity with the rice $C A B 2$-p in leaves of transgenic rice was $\approx 10$ times higher than with the $35 \mathrm{~S}$ promoter. In sweetpotato mature leaves, GUS activity directed by the constitutive $35 \mathrm{~S}$ promoter was approximately five times as high as that of rice $C A B 2-\mathrm{p}$. However, the expression level of the $C A B 2-\mathrm{p}-\mathrm{GUS}$ in sweetpotato leaves is much higher than reported in tobacco leaves (Sakamoto et al., 1991). Thus, both the rice CAB2-p and the $35 \mathrm{~S}$ promoter have great potential to direct high-level expression of linked genes in sweetpotato. In addition, further studies are still required to determine if the activity of the rice $C A B 2-\mathrm{p}$ is sufficiently active for directing transgene expression in sweetpotato leaves.

REgulation OF THE RICE CHLOROPHYLL A/B BINDING PROTEIN OF PHOTOSYSTEM-II PROMOTER. We have demonstrated that the rice $C A B 2-\mathrm{p}$ is developmentally regulated in sweetpotato plants with a higher level of $C A B 2-\mathrm{p}-\mathrm{GUS}$ in developing leaves versus old ones. This suggests that the rice $C A B 2-\mathrm{p}$ can be used to express herbicide- or disease-resistant genes targeted to sweetpotato leaves. Light regulation of the rice $C A B 2-p$ in sweetpotato is similar to what has been observed in $A$. thaliana transformed with various lightregulated promoters of $\mathrm{CAB}$ or $\mathrm{rbcS}$ genes (Gao and Kaufman, 1994).

In conclusion, the rice $C A B 2-p$ directed a leaf-specific, development-controlled, and light-regulated GUS expression in sweetpotato. Although the activity of the CAB2-p was $\approx 20 \%$ the activity of the $35 \mathrm{~S}$ promoter in mature leaves of sweetpotato, the leaf-specific manner of the CAB2-p enables its potential application for driving leaf-specific expression of transgenes in sweetpotato plant.

\section{Literature Cited}

Bischoff, F., A.J. Millar, S.A. Kay, and M. Furuya. 1997. Phytochrome-induced intercellular signaling activates $c a b$ ::luciferase gene expression. Plant J. 12:839-849.

Bradford, M.M. 1976. A rapid and sensitive method for the quantitation of microgram quantities of protein utilizing the principle of protein-dye binding. Anal. Biochem. 72:248-254.

Brusslan, J.A. and E.M. Tobin. 1992. Light-independent developmental regulation of $c a b$ gene expression in Arabidopsis thaliana seedlings. Proc. Natl. Acad. Sci. USA 89:7791-7795.

Chang, Y.C. and L.L. Walling. 1992. Spatial and temporal expression of $C a b$ mRNAs in cotyledons of the developing soybean seedling. Planta 186:262-272.

Churin, Y., E. Adam, L. Kozam-bognar, F. Nagy, and T. Börner. 2003. Characterization of two Myb-like transcription factors binding to $C A B$ promoters in wheat and barley. Plant Mol. Biol. 52:447462.

Gama, M.I.C., J.R.P. Leite, A.R. Cordeiro, and D.J. Cantliffe. 1996. Transgenic sweet potato plants obtained by Agrobacterium tumefaciens-mediated transformation. Plant Cell Tiss. Org. Cult. 46:237244.
Gao, J. and S. Kaufman. 1994. Blue-light regulation of the Arabidopsis thaliana Cab1 gene. Plant Physiol. 104:1251-1257.

Jefferson, R.A., T.A. Kavanagh, and M.W. Bevan. 1987. GUS fusions: $\beta$-glucuronidase as a sensitive and versatile gene fusion marker in higher plants. EMBO J. 6:3901-3907.

Kaldis, A.D., P. Kousidis, K. Kesanopoulos, and A. Prombona. 2003. Light and circadian regulation in the expression of $L H Y$ and Lhcb genes in Phaseolus vulgaris. Plant Mol. Biol. 52:981997.

Karlin-Neumann, G.A., L. Sun, and E.M. Tobin. 1988. Expression of light-harvesting chlorophyll a/b-protein genes is phytochromeregulated in etiolated Arabidopsis thaliana seedlings. Plant Physiol. 88:1323-1331.

Kay, S.A., A. Nagatani, B. Keith, M. Deak, M. Furuya, and N.-H. Chua. 1989. Rice phytochrome is biologically active in transgenic tobacco. Plant Cell 1:775-782.

Kimura, T., M. Otani, T. Noda, O. Ideta, T. Shimada, and A. Saito. 2001. Absence of amylose in sweet potato [Ipomoea batatas (L.) Lam.] following the introduction of granule-bound starch synthase I cDNA. Plant Cell Rept. 20:663-666.

Kretsch, T., K. Emmler, and E. Schäfer. 1995. Spatial and temporal pattern of light-regulated gene expression during tobacco seedling development: The photosystem II-related genes $L h c b(\mathrm{Cab})$ and $P s b p$ (Oee2). Plant J. 7:715-729.

Lamppa, G., F. Nagy, and N.-H. Chua. 1985. Light-regulated and organ-specific expression of a wheat $C a b$ gene in transgenic tobacco. Nature 316:750-752.

Linsmaier, E.M. and F. Skoog. 1965. Organic growth factor requirement of tobacco tissue cultures. Physiol. Plant. 18:100-127.

Luan, S. and L. Bogorad. 1992. A rice cab gene promoter contains separate cis-acting elements that regulate expression in dicot and monocot plants. Plant Cell 4:971-981.

Millar, A.J. and S.A. Kay. 1991. Circadian control of $C A B$ gene transcription and mRNA accumulation in arabidopsis. Plant Cell 3:541-550.

Morán, R., R. García, A. López, Z. Zaldúa, J. Mena, M. García, R. Armas, D. Somonte, J. Rodríguez, M. Gómez, and E. Pimentel. 1998. Transgenic sweetpotato plants carrying the delta-endotoxin gene from Bacillus thuringiensis var. tenebrionis. Plant Sci. 139:175-184.

Nagy, F., M. Boutry, M.-Y. Hsu, M. Wong, and N.-H. Chua. 1986. The $5^{\prime}$-proximal region of the wheat $\mathrm{Cab}-1$ gene contains a 268 -bp enhancer-like sequence for phytochrome response. EMBO J. 6:2537-2542.

Newell, C.A., J.M. Lowe, A. Merryweather, L.M. Booke, and W.D.O. Hamilton. 1995. Transformation of sweet potato [Ipomoea batatas (L.) Lam.] with Agrobacterium tumefaciens and regeneration of plants expressing cowpea trypsin inhibitor and snowdrop lectin. Plant Sci. 107:215-227.

Ni, M., D. Cui, J. Einstein, S. Narasimhulu, C.E. Vergara, and S.B. Gelvin. 1995. Strength and tissue specificity of chimeric promoters derived from the octopine and mannopine synthase genes. Plant J. 7:661-676.

Otani, M. and T. Shimada. 2002. Transgenic sweetpotato with agronomically important genes, p. 151-167. In: Khachatourians, G.G., McHughen A., Scorza R., Nip W.-K., and Hui Y.H. (eds.). Transgenic plants and crops. Marcel Dekker, New York.

Otani, M., Y. Wakita, and T. Shimada. 2003. Production of herbicideresistant sweetpotato [Ipomoea batatas (L.) Lam.] plants by Agrobacterium tumefaciens-mediated transformation. Breed. Sci. 53:145-148.

Piechulla, B., J.W. Kellmann, E. Pichersky, E. Schwartz, and H.H. Förster. 1991. Determination of steady-state mRNA levels of individual chlorophyll $\mathrm{a} / \mathrm{b}$ binding protein genes of the tomato $c a b$ gene family. Mol. Gen. Genet. 230:413-422.

Rogers, S.O. and A.J. Bendich. 1985. Extraction of DNA from milligram amounts of fresh, herbarium and mummified plant tissues. Plant Mol. Biol. 5:69-72. 
Sakamoto, M., Y. Sanada, A. Tagiri, T. Murakami, Y. Ohashi, and M. Matsuoka. 1991. Structure and characterization of a gene for light-harvest chl a/b binding protein from rice. Plant Cell Physiol. 32:385-393.

Simpson, J., J. Schell, M. Van Montagu, and L. Herrera-Estrella. 1986. Light-inducible and tissue-specific pea lhcp gene expression involves an upstream element combining enhancer and silencer properties. Nature 323:551-554.

Song, G.-Q., H. Honda, and K. Yamaguchi. 2004. Efficient Agrobacterium tumefaciens-mediated transformation of sweet potato [Ipomoea batatas (L.) Lam.] from stem explants using a two-step kanamycin-hygromycin selection method. In Vitro Cell. Dev. Biol. Plant 40:359-365.

Stomp, A.M. 1992. Histochemical location of $\beta$-glucuronidase, p. 103-113. In: Gallagher, S.R. (ed.). GUS protocols: Using the GUS gene as a reporter of gene expression. Academic Press, New York. Sugiyama, N., T. Izawa, T. Oikawa, and K. Shimamoto. 2001. Light regulation of circadian clock-controlled gene expression in rice. Plant J. 26:607-615.
Tada, Y., M. Sakamoto, M. Matsuoka, and T. Fujimura. 1991. Expression of a monocot lhcp promoter in transgenic rice. EMBO J. 10:1803-1808.

Thompson, W.F. and M.J. White. 1991. Physiological and molecular studies of light-regulated nuclear genes in higher plants. Ann. Rev. Plant Mol. Biol. 42:423-466.

Tsuchida, H., T. Tamai, H. Fukayama, S. Agarie, M. Nomura, H. Onodera, K. Ono, Y. Nishizawa, B.-H. Lee, S. Hirose, S. Toki, M.S.B. Ku, M. Matsuoka, and M. Miyao. 2001. High level expression of C4-specific NADP-malic enzyme in leaves and impairment of photoautotrophic growth in a $\mathrm{C}_{3}$ plant, rice. Plant Cell Physiol. 42:138-145.

Wakita, Y., M. Otani, T. Hamada, M. Mori, K. Iba, and T. Shimada. 2001. A tobacco microsomal $\omega-3$ fatty acid desaturase gene increases the linolenic acid content in transgenic sweet potato (Ipomoea batatas). Plant Cell Rept. 20:244-249.

Wilmink, A., B.C.E. Van de Ven, and J.J.M. Dons. 1995. Activity of constitutive promoters in various species from the Liliaceae. Plant Mol. Biol. 28:949-955. 